\title{
EFFECT OF ADDITIONAL GINGER (Zingiber officinale var. amarum) ON FEED ON THE GROWTH AND SURVIVAL LEVEL OF GOLDFISH (Cyprinus Carpio)
}

\author{
Nining Syafirah ${ }^{* 1}$, Muhammad Marzuki ${ }^{1}$, Baiq Hilda Astriana ${ }^{1}$ \\ ${ }^{1}$ Aquaculture Study Program, Faculty of Agriculture, University of Mataram \\ Jl Pendidikan No. 37 Mataram. NTB
}

\begin{abstract}
*Correspondence: niningsyafirah2@gmail.com
\end{abstract}

Received : 2021-12-21

Accepted : 2021-12-22

Keywords :

Goldfish, Ginger, Growth, Survival Rate.

\begin{abstract}
Goldfish is one of the most popular freshwater cultivated fish because it is one of the freshwater commodities that has economic value and is sold at a price that is affordable to all groups. Ginger is a natural ingredient that can stimulate fish growth. The purpose of this study was to determine the effect of adding ginger to feed and to determine a good dose of ginger for growth and survival rates of carp (Cyprinus carpio). This research was conducted by experimental method using completely randomized design (CRD) with 5 treatments and 3 replications. The treatments given were Treatment 1: 0 grams, without adding ginger / $\mathrm{kg}$ of feed (control), Treatment 2: 2.5 grams of ginger / kg of feed, Treatment 3: 5 grams of ginger rhizome / $\mathrm{kg}$ of feed, Treatment 4: 7.5 grams of ginger / kg of feed, Treatment 5: 10 grams of ginger / $\mathrm{kg}$ of feed. The results showed that the addition of ginger had no significant effect on absolute length growth, absolute weight growth, feed conversion ratio, and feed efficiency, but had a significant effect on the survival rate of goldfish (cyprinus corpio). And a good dose of ginger is in $\mathrm{P} 2$ treatment with a dose of 2.5 grams of ginger, because it has been able to show a good survival rate of $100 \%$.
\end{abstract}

\section{INTRODUCTION}

Goldfish (Cyprinus carpio) is one of the freshwater fish commodities belonging to the genus Cyprinidae. Goldfish is one of the freshwater cultured fish that is favored by the community both for consumption and as ornamental fish. Goldfish are popular because they are one of the freshwater commodities that have economic value and are sold at affordable prices by all people. The price of goldfish in general is $\mathrm{Rp} .30 .000 / \mathrm{kg}$ and this price is the benchmark price for West Lombok district (Rika et al., 2016). Apart from the price point of view, goldfish is widely consumed because it tastes delicious, savory and has a high nutritional content. Based on data obtained from the nutrition directorate of the Indonesian Ministry of Health (1981), carp contains 4.5 grams of protein, 23.1 grams of carbohydrates, and 0.2 grams of fat. In addition, carp contains calories (cal) 86, phosphorus (P) $134 \mathrm{mg}$, calcium (Ca) $42 \mathrm{mg}$, iron (Fe) $1 \mathrm{mg}$, Vitamin B1 $0.22 \mathrm{mg}$ and water as much as $71 \mathrm{mg} /$ head. This makes people's interest to consume goldfish increasing along with the increase in people's living standards. 
Journal of Fish Health Vol. 1 (2) - Dec 2021

Syafirah et al. (2021)

https://doi.org/10.29303/jfh.v1i2.530

Market demand for carp continues to increase from year to year, from 282,695 tons in 2010 to 484,110 in 2014 (KKP, 2015) and has increased production from 461,546 tons in 2015 to 498,297 tons in 2016 with an average increase by $7.43 \%$ per year (DGT, 2017 in Rahmad, 2015).

In meeting the increasing market demand, it is necessary to have a method that can stimulate fish growth. Efforts to increase the growth of carp can help farmers shorten production time, increase feed efficiency, minimize production costs and increase production yields. Several methods have been applied by cultivators, one of which is in the field of nutrition by using a variety of high-protein ingredients, especially those derived from vegetable materials as a substitute for fish protein, which has shown satisfactory results, but the price is quite expensive and unaffordable for farmers (Higgs et al., 2009 in Balseran and Manoppo, 2015), so that additional supplements from natural ingredients are needed that can stimulate fish growth.

Ginger is a natural ingredient that has the potential to stimulate fish growth. According to Cyahano et al. (2012), ginger is known to contain essential oils that have a fragrant aroma so that it can stimulate and arouse appetite and digestive glands, increasing the performance of enzymes that can help the digestive process in processing feed because ginger contains digestive enzymes, namely proteases and lipases, respectively. digest protein and fat, and ginger also contains antimicrobial and immunostimulating properties. In addition, according to Balseran and Manoppo (2015), ginger also contains vitamins A, B and C, each of which affects the growth of fish.

Previous research conducted on tilapia reared for four weeks showed that tilapia treated with ginger flour had three times greater growth than fish that were not treated (control fish) (Balseran and Manoppo, 2015). However, so far, literature studies that have been carried out show that the addition of ginger to carp (Cyprinus carpio) feed has never been applied. Based on this background, it is necessary to conduct research on the effect of using ginger in feed on the growth and survival rate of carp (C. carpio).

\section{METHODOLOGY}

This research was conducted for 48 days, from June 19, 2020, to August 5, 2020, at the Aquaculture Laboratory, Aquaculture Study Program, Faculty of Agriculture, Mataram University.

This research was conducted by experimental method using a completely randomized design (CRD) with 5 treatments and 3 replications to produce 15 experimental units. The treatments used were as follows: Treatment 1: 0 grams, without the addition of ginger $/ \mathrm{kg}$ feed (control), Treatment 2: 2.5 grams ginger $/ \mathrm{kg}$ feed, Treatment 3: 5 grams ginger $/ \mathrm{kg}$ feed, Treatment 4: 7,5 grams of ginger / kg of feed, Treatment 5: 10 grams of ginger / kg of feed.

The tools used in this research are containers, scales, aerators, hoses and aeration stones, waring, blender, sieve, seser, knife, stationery, tissue, small bucket, camera, pH meter, DO meter, thermometer, sprayer, and a ruler, and the materials used in this study were carp (Cyprinus carpio), ginger, aquades, commercial pellet feed, and fresh water. 
Journal of Fish Health Vol. 1 (2) - Dec 2021

Syafirah et al. (2021)

https://doi.org/10.29303/jfh.v1i2.530

Research procedure

Ginger Flour Making

First, the emprit ginger obtained from the market is washed and then peeled and sliced into thin pieces by splitting, then air-dried for 7 days (until dry and can be ground). The dried ginger is then made into flour using a blender and sifted to get a fine powder.

\section{Mixing Ginger in Feed}

The mixing of ginger in the feed begins with the ginger that has been in the form of flour weighed according to the required dose using a digital scale with an accuracy of $0.01 \mathrm{~g}$, then adjusted to Treatment 1: 0 grams, without the addition of ginger / $\mathrm{kg}$ of feed (control), Treatment 2: 2.5 grams of ginger / kg of feed, Treatment 3: 5 grams of ginger / kg of feed, Treatment 4: 7.5 grams of ginger / kg of feed, Treatment 5: 10 grams of ginger / kg of feed. The weighed ginger was then dissolved in a little distilled water $(100 \mathrm{ml}$ of distilled water in each treatment) then mixed evenly into the FF-888 commercial pellet feed by spraying it using a sprayer, then air-dried at room temperature. After drying, put it in a plastic box and store it in the refrigerator until it is used.

\section{Preparation of research containers and tools}

The maintenance container used is a container with a volume of 20 liters as many as 15 units. The containers are arranged according to the research plan. After the containers are clean and dry, an aeration hose and an aeration stone are installed in each container to supply oxygen in the maintenance container.

\section{Test Fish Preparation}

The fish used in this study were carp with an average length of 5-6 cm and an average weight of 2.8-6 grams. The fish used are healthy, move agile, and are not deformed.

Spread

The goldfish are selected first, then the fish are stocked in 15 containers with a volume of 20 liters. In 1 container of fish stocked with a density of 10 fish / 10 liters of water.

\section{Acclimatization}

Acclimatization was carried out for 3 days to prevent fish from being stressed by sudden changes in water media. During the three-day acclimatization process, the fish were fed commercial pellets that had not been treated with the at station method with a dose of $3 \%$ of the biomass, the frequency of feeding was 2 times a day at $08.00 \mathrm{am}$ and $16.00 \mathrm{pm}$. This is in accordance with the statement of Gusman and Muhammad (2014) in Mustofa et al. (2018) that the frequency of feeding carp is 2 times a day, namely at 08.00 and 16.00 WITA.

\section{Water Quality Management}

During maintenance, siphoning is carried out to remove the remaining faeces and uneaten feed from the container. Siphoning is done once a day, in the morning before feeding. Then do the water change as much as $30 \%$ (depending on the condition of the water) and the addition is carried out in proportion to the water removed. Measurement of water quality which includes temperature, $\mathrm{pH}$, and $\mathrm{DO}$. 
Journal of Fish Health Vol. 1 (2) - Dec 2021

Syafirah et al. (2021)

https://doi.org/10.29303/jfh.v1i2.530

Maintenance

Fish maintenance was carried out for 30 days to see the growth and survival rate of fish. Every 10 days the weight and length of the fish were weighed to determine the increase in length and weight of the fish and to determine the weight of the feed that would be given in the next 10 days.

Research Parameters

Absolute length growth

Absolute length growth (L) was calculated by the formula of Effendie (1997) in Saputra et al. (2018), as follows:

$$
\mathrm{L}=\mathrm{Lt}-\mathrm{Lo}
$$

Description:

L : Growth length $(\mathrm{cm})$

Lt : Length of fish at time $t(\mathrm{~cm})$

LO : Length of fish at the start of the study $(\mathrm{cm})$

Absolute weight growth

The average daily growth was calculated using the Effendie formula (2002) in Saputra et al. (2018), as follows:

$$
\mathrm{W}=\mathrm{Wt}-\mathrm{Wo}
$$

Description:

W : Absolute Growth(g)

Wt : Fish weight at time $\mathrm{t}(\mathrm{g})$

WO : Fish weight at the start of the study (g)

Feed Conversion Ratio

Parameters in showing efficiency in feeding during the study. The feed conversion ratio was calculated according to Effendie (1997) in Saputra et al. (2018), as follows:

Description:

$$
F C R=\frac{F}{(W t+D)-W o}
$$

FCR : Feed Conversion Ratio

F : : Total amount of feed given (g)

Wt : Total weight of fish at the end of the study (g)

Wo : Total weight of fish at the beginning of the study (g)

D : Weight of fish that died during the study (g)

\section{Feed Efficiency}

Comparison between the increase in body weight produced with the amount of feed consumed during maintenance. Feed Efficiency (EP) is calculated based on the formula Effendi (1997) in Saputra et al. (2018) as follows:

Description:

$$
E P=\frac{(W t+D)-W o}{F} X 100 \%
$$

EP : Feed Efficiency (\%)

$\mathrm{Wt}$ : Average weight of fish at the end of the study (g) 
Journal of Fish Health Vol. 1 (2) - Dec 2021

Syafirah et al. (2021)

https://doi.org/10.29303/jfh.v1i2.530

WO : Average weight of fish at the beginning of the study (g)

F : Total amount of fish feed given (g)

D : Weight of fish that died during the study (g)

Survival Rate

Fish survival was calculated using the Effendi (1978) formula in Widiastuti (2009) as follows:

Description:

$$
S R=\frac{N t}{N o} X 100 \%
$$

SR : Survival rate (\%)

$\mathrm{Nt} \quad$ : Number of live fish at the end of rearing (tails)

No : Number of fish at the beginning of stocking (tails)

Water quality

Water quality data is supporting data which includes temperature, DO and $\mathrm{pH}$. Data collection for $\mathrm{DO}$ and $\mathrm{pH}$ is done once a week. Meanwhile, temperature measurements were carried out every day, namely in the morning and evening.

Data analysis

Observation data on absolute length growth, absolute weight growth, feed conversion ratio, feed efficiency and survival rate were tested using Analysis of Variance (ANOVA) and if they were significantly different then continued with Duncan's test at $5 \%$ significance level, while the quality observation data water was analyzed descriptively.

\section{RESULT}

The results of this study showed that the addition of ginger to feed had no significant effect on absolute length growth, absolute weight growth, feed conversion ratio, feed efficiency, but gave a significant effect on the survival rate of carp.

\section{Absolute Length Growth}

The results of the analysis of variance (ANOVA) showed that the addition of ginger to feed had no significant effect on the absolute length growth of carp $(P>0.05)$. The results of absolute length growth can be seen in Figure 1.

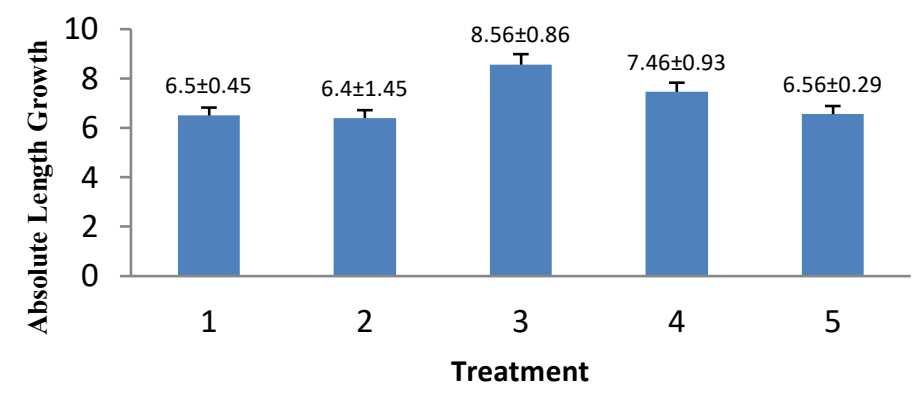

Figure 1. Graph of Absolute Length Growth of Goldfish (Cyprinus carpio) 
Journal of Fish Health Vol. 1 (2) - Dec 2021

Syafirah et al. (2021)

https://doi.org/10.29303/jfh.v1i2.530

Growth can be interpreted as an increase in length or weight over time. Based on the results of the analysis of variance (ANOVA) showed that the addition of ginger to the feed had an insignificant effect $(P>0.05)$ on the absolute length growth of carp.

\section{Absolute Weight Growth}

The results of the analysis of variance (ANOVA) showed that the addition of ginger to the feed had no significant effect on the absolute weight growth of carp ( $P>0.05)$. The results of absolute weight growth can be seen in Figure 2 .

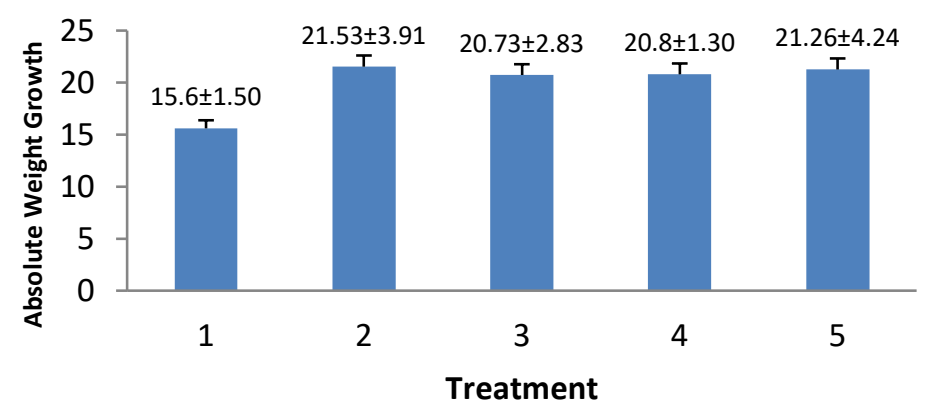

Figure 2. Graph of Absolute Weight Growth of Carp (Cyprinus carpio)

From the results of this study, the absolute weight growth of treatment P1 was 15.60 grams, treatment P2 was 21.53 grams, treatment P3 was 20.73 grams, treatment P4 was 20.80 grams, and the absolute weight growth for treatment P5 was 21.26 grams.

\section{Feed Conversion Ratio}

The results of the analysis of variance (ANOVA) showed that the addition of ginger to feed had no significant effect on the Feed Conversion Ratio of carp ( $P>0.05)$. The results of the feed conversion ratio can be seen in Figure 3.

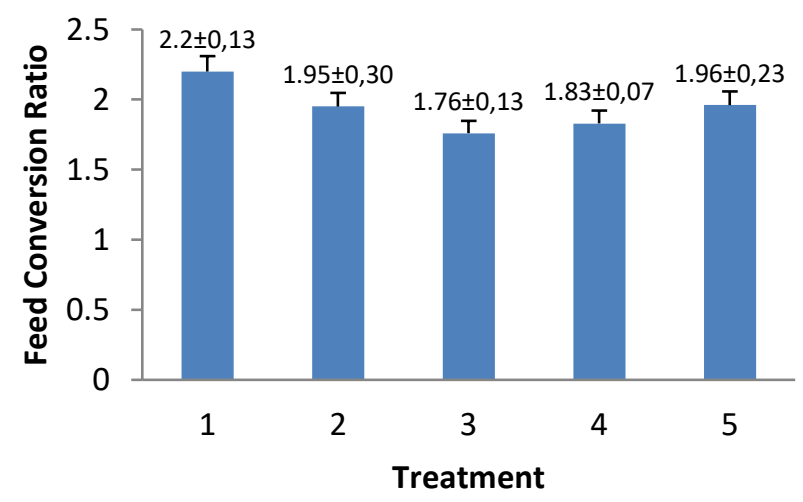

Figure 3. Graph of Carp (Cyprinus carpio) Feed Conversion Ratio

Based on the results of analysis of variance (ANOVA) showed that the addition of ginger to the feed had an insignificant effect on the Feed Conversion Ratio of carp ( $P>0.05)$. The feed conversion ratio graph in Figure 6 shows that, on average, the highest Feed Conversion Ratio was shown by carp without the addition of ginger to the feed with a feed conversion ratio 
Journal of Fish Health Vol. 1 (2) - Dec 2021

Syafirah et al. (2021)

https://doi.org/10.29303/jfh.v1i2.530

value of 2.20 , then followed by treatment 5 with the addition of ginger at a dose of 10 grams with a value of FCR of 1.96 , then treatment 2 with a dose of 2.5 grams with an FCR value of 1.76 , then treatment 4 with a dose of 7.5 grams of ginger with an FCR value of 1.83 , and the lowest FCR value was found in treatment 3 with a dose of 5 . grams of ginger with an FCR value of 1.76 .

\section{Feed Efficiency}

The results of the analysis of variance (ANOVA) showed that the addition of ginger to the feed had an insignificant effect on the feed efficiency of carp ( $P>0.05)$. The results of observations of Feed Efficiency (EP) can be seen in Figure 4.

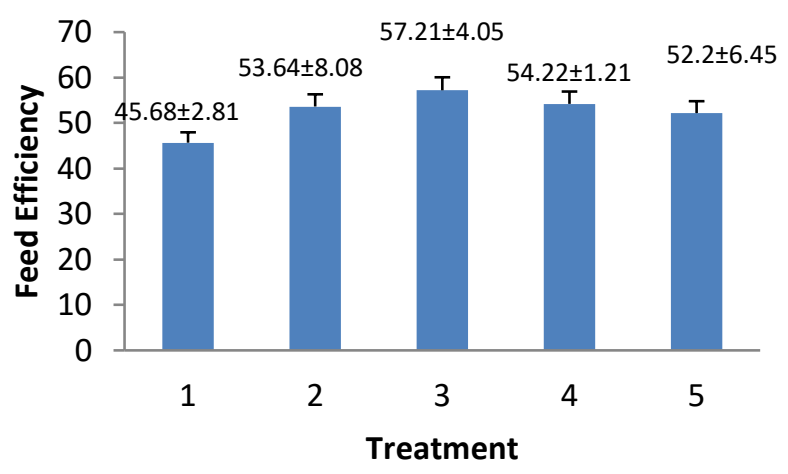

Figure 4. Graph of Feed Efficiency of Carp (Cyprinus carpio)

Feed efficiency is defined as the value of the ratio between the weight gain of fish and the weight of feed consumed during the rearing period expressed in percent. From the results of the research, the P1 treatment showed the feed efficiency value of $45.68 \%$, the P2 treatment of $53.64 \%$, the P3 treatment of $57.21 \%$, the P4 treatment of $54.22 \%$, and the P5 treatment of $52.20 \%$. The results of analysis of variance using one-way analysis of variance showed that the feed efficiency values were not significantly different $(P>0.05)$.

\section{Survival Rate}

Based on the results of the One-Way Annova test analysis showed that the addition of ginger feed had a significant effect $(P<0.05)$ on the survival of carp. The results of observations of the survival rate of goldfish can be seen in Figure 5.

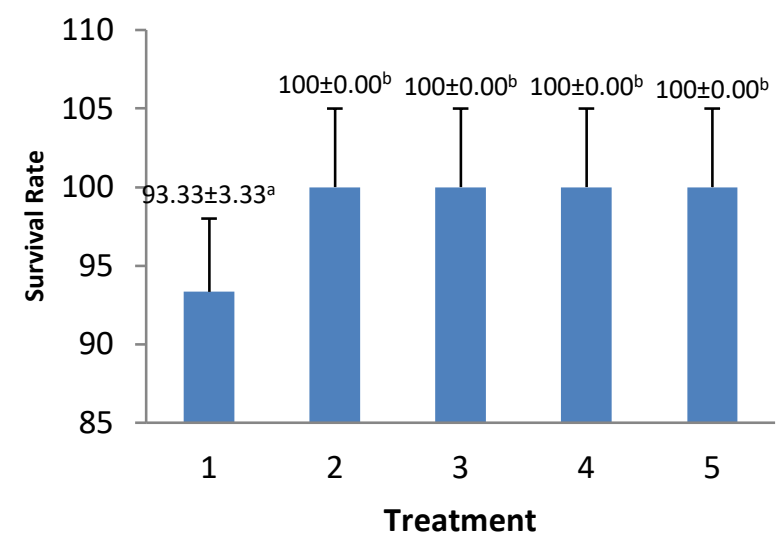


Journal of Fish Health Vol. 1 (2) - Dec 2021

Syafirah et al. (2021)

https://doi.org/10.29303/jfh.v1i2.530

Figure 5. Graph of Survival Rate of Goldfish (Cyprinus carpio)

Based on the graph of the survival rate, feeding with the addition of ginger showed a better survival rate than the treatment without the addition of ginger. In treatment P2, P3, P4, and P5 showed the same survival results, namely 100\%, while in P1 (Control) the survival scores were $93.33 \%$.

Water quality

Water quality is one of the external factors that can affect the growth of carp. The water quality parameters measured during the study can be seen in the table below.

Table 1. Water Quality Data

\begin{tabular}{|c|c|c|c|}
\hline Parameter & Treatment & Value Range & Eligibility Library \\
\hline \multirow[t]{5}{*}{ Temperatur $\left({ }^{\circ} \mathrm{C}\right)$} & P1 & $25.8^{\circ} \mathrm{C}-28.2^{\circ} \mathrm{C}$ & \multirow{5}{*}{$\begin{array}{l}25^{\circ} \mathrm{C}-32^{\circ} \mathrm{C} \\
\text { (Makaminan, 2011) }\end{array}$} \\
\hline & $\mathrm{P} 2$ & $26.2^{\circ} \mathrm{C}-28.1^{\circ} \mathrm{C}$ & \\
\hline & P3 & $26.2^{\circ} \mathrm{C}-28.5^{\circ} \mathrm{C}$ & \\
\hline & P4 & $26.1^{\circ} \mathrm{C}-28.2^{\circ} \mathrm{C}$ & \\
\hline & P5 & $26.3^{\circ} \mathrm{C}-28^{\circ} \mathrm{C}$ & \\
\hline \multirow[t]{5}{*}{ DO } & P1 & $4.3 \mathrm{mg} / \mathrm{l}-5.5 \mathrm{mg} / \mathrm{l}$ & \multirow{5}{*}{$\begin{array}{l}\text { >4 mg/l } \\
\text { (Wirahadi, 2014) }\end{array}$} \\
\hline & P2 & $4.3 \mathrm{mg} / \mathrm{l}-5.4 \mathrm{mg} / \mathrm{l}$ & \\
\hline & P3 & $4.3 \mathrm{mg} / \mathrm{l}-5.5 \mathrm{mg} / \mathrm{l}$ & \\
\hline & P4 & $4.4 \mathrm{mg} / \mathrm{l}-5.6 \mathrm{mg} / \mathrm{l}$ & \\
\hline & P5 & $4.3 \mathrm{mg} / \mathrm{l}-5.5 \mathrm{mg} / \mathrm{l}$ & \\
\hline \multirow[t]{5}{*}{$\mathrm{pH}$} & P1 & $7.6-7.9$ & \multirow{5}{*}{$\begin{array}{l}6,5-8,5 \\
\text { (Wirahadi, 2014) }\end{array}$} \\
\hline & P2 & $7.5-7.9$ & \\
\hline & P3 & $7.6-7.9$ & \\
\hline & P4 & $7.6-7.9$ & \\
\hline & P5 & $7.5-7.9$ & \\
\hline
\end{tabular}

The results of temperature observations during the study were found in the range of $25.80 \mathrm{C}-28.50 \mathrm{C}$. Meanwhile, the DO measurement results during the study showed that DO range from $4.3 \mathrm{mg} / \mathrm{l}-5.6 \mathrm{mg} / \mathrm{l}$. And for the $\mathrm{pH}$ value on the maintenance media during the study ranged from 7.5-7.9.

\section{DISCUSSION}

From the results of this study, the absolute length growth of treatment $P 1$ is $6.50 \mathrm{~cm}$, treatment P2 is $6.40 \mathrm{~cm}$, treatment $\mathrm{P} 3$ is $8.56 \mathrm{~cm}$, treatment $\mathrm{P} 4$ is $8.13 \mathrm{~cm}$, and the absolute length growth is treatment P5 is $6,56 \mathrm{~cm}$. The difference in absolute length growth which was relatively small between the treatments in this study was presumably because the doses of ginger used, namely 2.5 grams, 5 grams, 7.5 grams, 10 grams, were not appropriate and did not influence the length growth of carp, thus showing inconsistent results really different. The absolute length growth that was not significant between the control treatment and the treatment with the addition of ginger in this study was presumably because the ginger material added to the feed was already scattered in the rearing media at the time of feeding the test animals. The spread of ginger material in the feed was probably due to the use of the direct spraying method on the feed being less effective and the ginger not absorbing into the feed so that it did not provide any effect and benefit on the growth of carp. In addition, it can be noticed that on the maintenance media there are remnants of ginger stuck to the 
Journal of Fish Health Vol. 1 (2) - Dec 2021

Syafirah et al. (2021)

https://doi.org/10.29303/jfh.v1i2.530

maintenance media. This causes the content contained in ginger such as vitamin A and vitamin $B$ which should be able to stimulate the growth of carp does not have such a significant effect on the growth of carp. Azrimaidaliza (2007) stated that Vitamin A affects protein synthesis, namely cell growth. Vitamin A is needed for bone development and growth. While vitamin B has benefits as described by Yuniati and Almasyhuri (2012), it can accelerate growth, accelerate cell regeneration, formation of red blood cells, and maintain immunity and tissue formation.

Growth is not only influenced by feed but can also be influenced by other factors such as genetic characteristics of fish, physiological conditions of fish, digestibility of feed and other factors. In addition, the growth of fish length is influenced by the space and movement of the fish itself. This is reinforced by Prihadi (2007) which states that growth is influenced by several factors, namely internal and external factors, while internal factors include heredity, disease resistance and ability to utilize food, and fish size. while external factors include physical, chemical and biological characteristics of the waters. In addition, fish growth patterns can be caused by other factors. Kusmini et al (2018) state that growth can be influenced by biological factors related to genetic body shape, age, size, gender in a species, it can also be influenced by individual fitness conditions, food availability, and individual growth.

Based on the results of the analysis of variance (ANOVA) showed that the addition of ginger to the feed had an insignificant effect $(P>0.05)$. This indicated that the addition of ginger to the feed had no significant effect on the absolute weight growth of carp. The addition of ginger to the diet in this study showed contradictory results from previous studies. Belseran and Manopo (2015) stated that fish that were treated with ginger had a body weight of about three times greater than the body weight of fish that were not treated with ginger. Similar results were reported by Nya and Austin (2009) where rainbow trout (Oncorhyncus mykiss) fed a diet with the addition of ginger as much as $1-10 \mathrm{~g} / \mathrm{kg}$ feed resulted in a significant increase in growth compared to the growth rate of fish that were not treated with ginger (control).

The difference in absolute weight growth that was not significant between the treatments in this study was presumably because the doses of ginger used, namely 2.5 grams, 5 grams, 7.5 grams, 10 grams were not appropriate and did not influence the weight growth of carp. In addition, the absolute weight growth that was not significant in this study was presumably because the ginger material added to the feed was already spread in the rearing media at the time of feeding the test animals. The spread of ginger material in the feed was probably due to the ineffective use of the direct spraying method on the feed, so that the ginger was not absorbed properly and had less effect and benefit on the growth of carp. In addition, it can be noticed that on the maintenance media there are remnants of ginger stuck to the maintenance media.

The feed conversion ratio is the ratio of the amount of feed needed to produce $1 \mathrm{~kg}$ of cultured fish meat. Figure 6 shows that, on average, the highest feed conversion ratio was displayed by carp without adding ginger to the feed with a feed conversion ratio value of 2.20, namely in treatment 1 , then followed by treatment 5 with the addition of ginger at a dose of 10 grams. The feed conversion ratio in treatment 1 without the addition of ginger was 2.20 higher than the other treatments. This indicates that the feed quality of the control treatment was less good than the other treatments. Sanoesi et al (2003) in Susanti (2004) stated that a high feed conversion value means that the quality of the feed provided is not good. The quality of a feed is not only seen from the value of feed efficiency but can also be shown from the value of feed conversion. The lower value indicates that the food that can be 
Journal of Fish Health Vol. 1 (2) - Dec 2021

Syafirah et al. (2021)

https://doi.org/10.29303/jfh.v1i2.530

utilized in the body is better, and the quality of the food is better too, because giving the same amount of feed will give a higher body weight gain. However, the FCR value in this study was considered high and not good because according to DKPD (2010) in Ihsanudin et al (2014) the value of the food conversion ratio (FCR) was quite good ranging from 0.8 to 1.6. Gusman and Muhammad (2014) in Jasansong (2020) also reported that carp fed with a dose of $3 \%$ of the total biomass had an FCR value ranging from 1.2 to 1.6. The FCR value that is not good in this study is thought to be because the nutrients and content of ginger are not absorbed by the fish's body, because the FCR value is closely related to the nutrients contained in the feed and the quality of the feed. In addition, Shofura et al (2017) stated that the size of the feed conversion ratio was thought to be due to the absorption of different nutrients in each species, age, size and number of test fish.

The test results showed that the addition of ginger to feed had no significant effect on the efficiency of carp feed. According to Marzuqi et al (2012), feed efficiency shows how much feed can be utilized by fish. Low feed efficiency values indicate that fish need more feed to increase their weight. According to Kordi (2011) in Hidayat (2013), the higher the feed efficiency value, the more efficient the use of feed by fish. Based on the results of the research that has been done, the value of feed efficiency in the treatment of P2, P3, P4, and P5 is quite good, because it ranges from $57.21 \%-52.20 \%$. This is in accordance with the statement of Puspasari et al (2015) in Mustofa et al (2018), where the efficiency of using good feed for fish in general is more than $50 \%$ or even close to $100 \%$. While the treatment without the addition of ginger rhizome (control) showed a poor feed efficiency value of $45.68 \%$ or less than $50 \%$. The poor feed efficiency value in the control treatment was thought to be due to the absence of adding ginger to the feed, because ginger contains volatile oils that can increase fish appetite so that the feed can be utilized efficiently. This is reinforced by Chyano et al (2012), ginger is known to contain essential oils that have a fragrant aroma so that it can stimulate and arouse appetite and digestive glands. In addition, the efficiency of feed utilization is closely related to the digestibility of fish to the feed given. According to Yanti et al (2013), the digestibility of fish to a feed is influenced by several factors, namely the chemical nature of water, water temperature, type of feed, size and age of fish, nutritional content of feed, frequency of feeding and the number and types of digestive enzymes contained in the feed. fish digestive tract.

Judging from the economic aspect, the recommended dose that should be used is P2 with a dose of 2.5 grams $/ \mathrm{kg}$ of feed because with this dose it has been able to provide good survival results in goldfish. The high survival rate of fish fed with the addition of ginger is thought to be because ginger contains vitamin $C$ which can maintain resistance and prevent stress so that the survival rate of fish is high. This is in accordance with the statement of Robiansyah et al (2018) which states that the function of vitamin C is to increase and also normalize the immune system so as to prevent stress on fish fry. In addition, according to Marzuki et al (1997) in Purwati et al (2015) vitamin C deficiency in aquatic organisms, for example, is characterized by low growth, easy stress, and high mortality. In addition to the use of ginger added to the feed, the survival rate is supported by good water quality control, this is in accordance with Boyd (1998) in Syawal et al (2008) that a good environment will increase fish resistance, while a poor environment This will cause the fish to be easily stressed and reduce their resistance to bacterial attack. According to Yulianto (2006) in Vardian et al (2013) graduation of life is influenced by internal factors and external factors, where internal factors are factors of the individual fish, and external factors are factors that are influenced by feed quality and water quality. 
Journal of Fish Health Vol. 1 (2) - Dec 2021

Syafirah et al. (2021)

https://doi.org/10.29303/jfh.v1i2.530

Water quality plays an important role in the media where fish live. Water quality parameters measured during the study were temperature, $\mathrm{DO}$, and $\mathrm{pH}$. Temperature is a condition that describes the hot and cold waters. Temperature also affects the level of fish appetite and resistance to disease. The results of temperature observations during the study obtained a range of $25.8{ }^{\circ} \mathrm{C}-28.5^{\circ} \mathrm{C}$. This temperature range is still within a reasonable range in carp culture. This statement is in accordance with Makaminan (2011) in Darwis et al (2019), that the optimum temperature range for fish life is between $25{ }^{\circ} \mathrm{C}-32{ }^{\circ} \mathrm{C}$.

Dissolved Oxygen (DO) is a condition that describes the presence or absence of dissolved oxygen in the waters. Dissolved oxygen is one of the limiting factors that are needed by fish to live. Based on the results of DO measurements during this study, it was found that DO range from $4.3 \mathrm{mg} / \mathrm{l}-5.6 \mathrm{mg} / \mathrm{l}$. The range of dissolved oxygen is still within normal levels for carp cultivation. This statement is in accordance with Wirahadi (2014) in Darwis et al (2019), dissolved oxygen levels in waters or in ponds that are good for carp growth are $>4$ $\mathrm{mg} / \mathrm{l}$.

$\mathrm{pH}$ is a state of water, both acidic and basic. The high and low $\mathrm{pH}$ of a waters is influenced by the presence of chemicals, both organic and inorganic, such as feed residues and faeces in the fish that are kept. The $\mathrm{pH}$ value of the maintenance medium during the study ranged from 7.5-7.9. The $\mathrm{pH}$ value is still within the normal range for goldfish life. This statement is in accordance with Wirahadi (2014) in Darwis et al (2019), a good pH value for carp cultivation ranges from 6.5 to 8.5. The $\mathrm{pH}$ value of a waters can affect the growth of the biota in it, it can even cause death for the biota. This is supported by Copatti et al (2011) in Mustofa (2018) which states that a neutral and slightly alkaline $\mathrm{pH}$ is recommended for freshwater fish. According to Nirmala et al (2012) that the lethal pH for fish is less than 4 and more than 11, while a $\mathrm{pH}$ of 6.5 and more than 9.5 in a few hours will affect the growth and production of fish.

\section{CONCLUSION}

The results showed that the addition of ginger mixed with carp feed had an insignificant effect on absolute length growth, absolute weight growth, feed conversion ratio, and feed efficiency, but had a significant effect on the survival rate of carp (Cyprinus corpio). Judging from the results of the survival rate, a good dose of ginger was in the P2 treatment with a ginger dose of 2.5 grams $/ \mathrm{kg}$ of feed, because it was able to show a good survival rate of $100 \%$.

\section{ACKNOWLEDGMENT}

The authors thank the University of Mataram for accommodating and facilitating this research.

\section{REFERENCES}

Adliah, N. (2011). Income Analysis of Carp Processing Business (Cyprinus carpio) Financial Statement Perspective (Case Study on Limbung Mas Indah Business, Kalebajeng Village, Bajeng District, Gowa Regency). Essay. Fisheries Socio-Economic Study Program, Department of Fisheries, Faculty of Marine and Fisheries Sciences, Hasanuddin University. Makassar. 
Alminiah, A. (2015). Control of Ectoparasites in Carp (Cyprinus carpio L.) Seeds with the Addition of Kitchen Salt $(\mathrm{NaCl})$ at the Plalangan Kalisat Fisheries Seed Center, Jember Regency. Essay. Department of Biology, Faculty of Mathematics and Natural Sciences, University of Jember. Jember.

Aryanti, I., Bayu, ES, Kardhinata, EH (2015). Identification of Morphological Characteristics and Relationships in Ginger (Zingiber officinale Rosc.) in Dolok Saribu Village, Simalungun Regency. Online Journal of Agroecotechnology, 3(3): 2337-6597.

Azrimaidaliza. (2007). Vitamin A Immunity and Its Relation with Infectious Diseases. Journal of Public Health. PSIKM FK UNAND.

Balseran, L. and Manoppo, H. (2015). Utilization of Ginger (Zingiber Officenale Rosc) to Stimulate the Growth of Tilapia (Oreochromis niloticus). Journal of Aquaculture, 3(1): 4350.

Cahyono, ED, Atmomarsono, U., Saprijanta, E. (2012). The Effect of Using Ginger Flour (Zingiber Offinale) in the Ration on the Digestive Tract and Liver of 12-weekold native chickens. Animal Agriculture Journal, 1(1): 65-74.

Hidayat, D., Ade, D, S., Yulisman. (2013). Survival, Growth and Feed Efficiency of Snakehead Fish (Channa Striata) which was fed with Gold Conch Flour (Pomacea $S p$ ) as raw material. Indonesian Journal of Swamp Aquaculture, 1(2):161-172.

Ihsanudin, I., Sri, R., Tristiana, Y. (2014). Effect of Administration of Recombinant Growth Hormone (Rgh) Through Oral Methods with Different Time Intervals on Growth and Survival of Seeds of Larasati Tilapia (Oreochromis niloticus). Journal Of Aquaculture Management and Technology, 3(2): 94-102.

Jasansong, K., Indra, R, N., Salindeho., Reni, L., Kreckhoff. (2020). Growth of Cyprinus carpio carp fry fed with different doses of feed in a garden pond with a recirculation system. Journal of Aquaculture, 8(1): 1-7.

Marzuqi, M., NW Astuti and K. Suwirya. (2012). Effect of Protein Content and Feed Ratio on Growth of Tiger Grouper (Epinephelus fuscoguttatus). BBPP Gondol Marine Cultivation, Bali. 4(1) : 55-65.

Mustofa, A., Hastuti, S., Rachmawati, D. (2018). Effect of Fasting Period on Feed Utilization Efficiency, Growth and Survival of Carp (Cyprinus carpio). Journal Of Aquaculture Management and Technology, 7(1): 18-27.

Nirmala, PDY (2018). The Effect of Addition of Variations of Ginger Extract (Zingiber Officenal) on the Quality of Organoleptic Sevara Yoghurt. Essay. Biology Education Study Program Department of Mathematics and Natural Sciences Education Faculty of Teacher Training and Education, University of Sanata Dharma. Yogyakarta.

Nirmala, K., Yani, H., and Riza PW (2012). Addition of Salt in Water Media Containing Zeloites and Activated Charcoal in Closed System Transportation of Gourami Seed (Oshpronemus goramy Lac.). Indonesian Journal of Aquaculture, 11(2) : 190-201

His EJ, Austin B. (2009). Use of dietary ginger, Zingiber officinale Roscoe, as an Immunostimulant to control Aeromonas hydrophila infections in rainbow trout, Oncorynchus mykiss (Walbaum). Journal of Fish Diseases, 32:971-977

Prihadi, DJ (2007). Effect of Type and Time of Feeding on Survival Rate and Growth of Tiger Grouper (Epinephelus Fuscoguttatus) in Floating Net Cages at Lampung Marine Cultivation Center. Faculty of Fisheries and Marine Sciences, Padjadjaran University. Bandung. Indonesian Journal of Aquaculture. 
Journal of Fish Health Vol. 1 (2) - Dec 2021

Syafirah et al. (2021)

https://doi.org/10.29303/jfh.v1i2.530

Purwanti, R., Susanti, R., Martuti, NKT 2012. Effect of Ginger Extract on reducing the number of protozoan ectoparasites in tiger grouper seeds. Unnes Journal of Life Science, 1(2): 2252-6277.

Putranti, G, P., Subandiyono., Pinandoyo. (2015). Effect of Different Protein and Energy on Artificial Feed on Feed Utilization Efficiency and Growth of Carp (Cyprinus carpio). Journal of Aquaculture Management and Technology, 4(3): 38-45

Rahmad, D., Adelina., Heltonika, B. (2015). Utilization of Fermentation of Cassava Leaves (Manihot Utilissima) in Artificial Feed on Growth and Graduation of Gourami (Osphronemus Gouramy Lac) Seeds. Essay. Faculty of Fisheries and Marine Sciences, University of Riau. Riau.

Rika, NP, Usman, A., Maryati, S. (2016). Value chain analysis of freshwater fish marketing in West Lombok district. Journal of Agroteksos: 1-9.

Robiansyah., Eka, I, R., Farida. (2018). The Effectiveness of Adding a Dosage of Ginger Rhizome Flour (Zingiber Officinale Rosc) in Feed to Stimulate the Growth of Teak Fish (Barbonymus Schwanenfeldii) Seeds. Ruaya Journal, 6(1).

Rozi., Akhmad, T, M., Syifania, H, S., Muhammad, B, S. (2018). Effect of Chitosan in Feed on Growth, Survival and Efficiency of Feed Utilization of Tilapia (Oreochromis niloticus). Journal of Fisheries, Gadjah University, 20 (2): 103-111.

Saputra, I., Putra, WKA, Yulianto, T. (2018). Conversion Rate and Feed Efficiency of Star Pomfret (Trachinotus blochii) Seeds with Different Feeding Frequency. Journal of Aquaculture Science, 3(1): 170-181.

Shofura, H., Suminto., D. Chilmawati. (2017). Effect of Addition of "Probio-7" to Artificial Feed on Feed Utilization Efficiency, Growth and Survival of Gift Tilapia (Oreochromis niloticus) Seeds. Journal of Tropical Aquaculture Science, 1(1): 10-20.

Sugianto, D. (2007). Effect of maggot feeding rate on growth and efficiency of carp (Osphronemus gouramy) seed feeding. Essay. Bogor Agricultural Institute. Faculty of Fisheries and Marine Science. Department of Aquaculture. Bogor.

Sugiyono. (2012). Qualitative Quantitative Research Methods and R\&D. Bandung: Alphabeta. Sulawesty F., Tjandra, C., Endang, M. (2014). Growth Rate of Carp (Cyprinus Carpio L) by Feeding Fresh Lemna (Lemna Perpusilla Torr) in Closed Flow System Ponds. Limnotek Journal, 21(2).

Susanti, D. 2004. Effect of Addition of Various Silage of Fishery Products in Feed Ration on Growth and Survival of Gift Tilapia Seeds. Essay. Diponegoro University.

Syawal, H., Syafriadiman., Syauqi, H. (2008). Provision of Siwak Wood Extract (Salvadora Persica L.) To Increase Immunity of Carp (Cyprinus Carpio L.) Raised in Cages. BIODIVERSITY, 9(1) : 44-47.

Tresna, L, K., Yayat, D., Titin, H. 2012. Food Habits and Fish Niche Area in the Upper Cimanuk River, Garut Regency, West Java. Journal of Fisheries and Marine Affairs, 3(3): 163173.

Vardian, A, K., Subandiyono., Pinandoyo. 2013. The Effect of Different Strains of Tilapia F5 (Larasati, Red, Black) which were fed with an E/P Value of $10.96 \mathrm{Kcal} / \mathrm{G}$ Protein on Growth and Survival. Journal Of Aquaculture Management and Technology, 2(4): 108114.

Wihartyas, FV (2015). The Effectiveness of Giving Carp (Cyprinus carpio) in Reducing the Number of Larvae and Their Community Perception (Case Study in Rw 06, Sukorejo Village, Gunungpati District, Semarang City). Essay. Department of Public Health Sciences, Faculty of Sports Science, State University of Semarang. Semarang. 
Journal of Fish Health Vol. 1 (2) - Dec 2021

Syafirah et al. (2021)

https://doi.org/10.29303/jfh.v1i2.530

Yanti, Z., ZA Muchlisin, Sugito. (2013). Growth and Survival of Tilapia (Oreochromis niloticus) Seeds at Several Concentrations of Jaloh Leaf Flour (Salix tetrasperma) in Feed. Journal of Fisheries and Aquatic Sciences, 2(1): 16-19.

Yuniati., Almasyhuri. (2012). Contains Vitamins B6, B9, B12 And E Several Types of Meat, Eggs, Fish and Sea Shrimp in Bogor And Surrounding Areas. Center for Biomedical and Basic Health Technology, Research and Development Agency, Ministry of Health, Republic of Indonesia JI. State Printing 29 Jakarta. Food Nutrition Board 2012, 35(1): 7889. 